JIC

22,2

290

Received 28 February 2020

Revised 3 June 2020

2 July 2020

30 July 2020

Accepted 31 July 2020

\section{Managing intellectual capital in healthcare organizations. A conceptual proposal to promote innovation}

\author{
Hui Huang \\ School of Accountancy, Chongqing Technology and Business University, \\ Chongqing, China \\ Daniele Leone and Andrea Caporuscio \\ University of Naples-Parthenope, Napoli, Italy, and \\ Sascha Kraus \\ Durham University, Durham, UK
}

\begin{abstract}
Purpose - The present article aims at rising stream of literature about intellectual capital in healthcare organizations, by exploring how knowledge-based activities are designed to promote innovation and create value. This process concerns not only buyers and sellers of industrial products/services but, more widely, larger networks of healthcare actors which include patients, payers and health institutions.

Design/methodology/approach - To answer the research question, we adopted a conceptual approach aimed at reaching overall comprehension of healthcare innovation mechanisms. We have tracked the pivotal extant studies for catching the roots and dynamics at the base of diffusion of healthcare innovation. This article demonstrates, based on previous literature and theoretical speculations, the contribution that innovative knowledge-based activities (e.g. market access approach) make to intellectual capital in healthcare organizations to promote innovation and create value.

Findings - The results show that three knowledge-based activities of the healthcare ecosystem shape the basis of the proposed conceptual framework. First, a value co-creation strategy to develop capabilities for each health stakeholder is intended as human capital. Second, the market access approach to promote innovation is reported to the relational capital. Third, a digital servitization strategy is referred to the structural capital.

Research limitations/implications - This paper provides implications for the stream of literature about intellectual capital in healthcare organizations. It aims at exploring three knowledge-based activities as value co-creation, market access and digital servitization that respond to different intellectual capital levels components (human, relational, structural).

Originality/value - This article provides a conceptual framework based on the linkage of two fundamental streams of management studies, which correspond to innovation diffusion and intellectual capital management. This offers a more solid conceptualization for managing intellectual capital in healthcare organizations with respect to previous studies and creates value in the ecosystem.
\end{abstract}

Keywords Intellectual capital, Healthcare, Market access, Innovation process, Digital servitization, Value co-creation

Paper type Research paper

\section{Introduction}

In the past two decades, a wide range of studies have turned their interest to exploring intellectual capital for performance management practices in the healthcare industry (Peng

(c) Hui Huang, Daniele Leone, Andrea Caporuscio and Sascha Kraus. Published by Emerald Publishing Limited. This article is published under the Creative Commons Attribution (CC BY 4.0) licence. Anyone may reproduce, distribute, translate and create derivative works of this article (for both commercial and non-commercial purposes), subject to full attribution to the original publication and authors. The full terms of this licence may be seen at http://creativecommons.org/licences/by/4.0/legalcode
Journal of Intellectual Capital Vol. 22 No. 2, 2021 pp. $290-310$

Emerald Publishing Limited 1469-1930

DOI 10.1108/JIC-02-2020-0063 
et al., 2007; Pirozzi and Ferulano, 2016; Cavicchi, 2017). Recent scholars have attested to the development of knowledge-based activities as an important factor in adopting innovation in every healthcare organization and institution (Piri and Asefzadeh, 2006; Peng et al., 2007; Mura et al., 2012). These service-based organizations are intended as knowledge-producing systems and as nodes in knowledge-exchanging systems (Kogut and Zander, 1992; Greenhalgh et al., 2008). In the last few years, health organizations have seen the transition to a business model focused on patient needs and composed of a plurality of stakeholders (e.g. physicians, payers, decision makers) who actively participate in the challenges of the health context (Omachonu and Einspruch, 2010). Thus, knowledge sharing among these various actors has become fundamental in order to guarantee services' quality to be provided.

With reference to the importance of knowledge in the innovation decision process, Rogers (2003) defined the adoption process as "the process through which an individual or other decision-making unit passes from first knowledge of an innovation, to forming an attitude toward the innovation, to a decision to adopt or reject, to implementation of the new idea, and to confirmation of this decision". The adoption decision can also involve the analysis of cost and benefits (Greenhalgh et al., 2004). Other scholars have also noted the limits to the diffusion of innovation that is influenced by technological, social and learning "conditions" while operating in the contextual "domain" of the individual, community or market/industry (MacVaugh and Schiavone, 2010). For instance, the existence of complementary technologies can positively influence the diffusion and adoption of new technology (Gandal et al., 2000), but can also represent a weakness for the community or market/industry. It is the case of new pharmaceutical mechanisms that thanks to technological innovation are labelled as new spectrum of medical products equipped by disruptive therapeutic features (Ciani et al., 2016).

In the health context, past attention did not focus on the fragmented power of different health operators and, more importantly, on its effect on the relationship between companies, patients and health stakeholders with regard to clinical and economic outcomes (Dansky and Gamm, 2004). For these reasons, intellectual capital and its components (human capital, relational capital and structural capital) have become key value drivers for service-based organizations such as those for healthcare (Kianto et al., 2010). Evans et al. (2015) identified the advantages of intangible resources in healthcare organizations, especially in systematically managing these resources together, and their mutually increasing interactions to promote innovation. These intangible resources can manage several dynamics (e.g. changing decisionmaking power) of the current healthcare environment to support innovation. For instance, recent healthcare management studies established the fundamental role of market access (MA) strategies in marketing authorization and in promoting innovations in pharmaceutical products (e.g. drugs or medical devices) (Koch, 2015; Toumi, 2017).

The present article aims at contributing to the rising stream of literature about intellectual capital in healthcare organizations (e.g. Peng et al., 2007; Pirozzi and Ferulano, 2016; Cavicchi, 2017; Paoloni et al., 2020) in a service-based ecosystem perspective (Chou et al., 2018) by exploring how these knowledge-based activities (e.g. MA practices in healthcare) are designed and implemented to promote innovation and create value not only for buyers and sellers of industrial products/services but, more widely, for larger networks of healthcare actors. Indeed, our research question is: "how do knowledge-based activities enable to the intellectual capital to promote innovation? Using a conceptual approach based on the literature analysis carried out, the management of intellectual capital is fundamental to understand whether healthcare organizations can promote innovations providing benefits and value to patients, health institutions and other stakeholders. As a result, three knowledge-based activities of the healthcare ecosystem shape the basis of the proposed conceptual framework.

First, a value co-creation strategy to develop capabilities for each health stakeholder is intended as human capital. From this perspective, recent literature examined the value cocreation process focusing not only on the skills of general physicians or the performance of 
medical devices; for these reasons, we focus on the knowledge sharing activities at the level of a patient who seems to be more indicated in intellectual capital exploitation to co-create value (Piri and Asefzadeh, 2006; Camelo-Ordaz et al., 2011; Bordoloi et al., 2012). Second, the MA approach to promote innovation is reported to the relational capital. Market access managers (MAMs) of pharmaceutical companies have developed specific knowledge in pricing and reimbursement strategies, public affairs and supply conditions that reduce the time to market for drugs or medical devices. Indeed, Robinson (2010) defined the MA as a "strategic planning to ensure that the new products are adopted by key stakeholders and therefore accessible upon approval and launch with minimum barriers to use". Third, a digital servitization strategy is referred to the structural capital. This activity adds value to a product by furnishing one or more coupled digitalized services (Vandermerwe and Rada, 1988; Baines et al., 2017). Additionally, digitalization enables knowledge sharing by harnessing the ability to attract end users and the capacity to break down the barriers between goods suppliers and information flows (Nambisan et al., 2017; Autio et al., 2018).

Our research provides theoretical implication for the emerging stream of literature about intellectual capital in healthcare organizations (Evans et al., 2015; Pirozzi and Ferulano, 2016; Cavicchi, 2017) by exploring particular knowledge-based activities explored as new practices that could be adopted by companies and able to support the diffusion of innovations in a service-based ecosystem as health. Indeed, we highlight new insights in order to offer practical implications to the company managers able to create shared values between the different stakeholders involved in the decision-making process to improve the sustainability of the entire ecosystem. This conceptual paper also has several managerial implications for MAMs who face in the health ecosystem for the diffusion of new drugs or medical devices. The main limit of this conceptual paper is referred to the intellectual capital intended as a relevant factor, but we know that is not the only factor involved in the process of healthcare innovation.

The article is organized as follows: after this introduction, Section 2 reviews the theoretical background of the conceptual paper. Section 3 describes the methodology. Section 4 defines a conceptual proposal for managing intellectual capital in healthcare organizations and presents the main results. Section 5 discusses the findings and the main implications. Conclusions are illustrated in Section 6.

\section{Theoretical background}

\subsection{Innovation and knowledge in the healthcare ecosystem}

In the management literature, the concept of "innovation" in all its different forms still occupies a crucial role in the works of academic scholars. Initial discussions about the importance of knowledge in the innovation decision process have been developed by Rogers (2003), who conceptualized five main steps in the process of deciding to adopt or reject innovation: 1) knowledge, 2) persuasion, 3) decision, 4) implementation and 5) confirmation. Thus, knowledge represents the first moment from when a customer has consciousness of an innovation until he or she has used it. As affirmed by Darroch (2005), "a firm with a knowledge management capability will use resources more efficiently and so will be more innovative and perform better". In other words, the contribution of Darroch (2005) provided a tight linkage between the availability of resources and knowledge and their conversion into useful and effective capabilities. Ferraris et al. (2017) supported Darroch's concept by investigating the positive correlation between external research, R\&D skills and innovation performance when greater the management is characterized by greater level of level of knowledge management capabilities.

Research progress has brought the implementation of innovative tools (e.g. digital platforms) to exchange knowledge and to transmit information in real time. These new practices have led to an understanding of the huge complexity of innovation studies. Indeed, innovation theories have been influenced by various economic and political thinkers in the 
last centuries, such as Schumpeter (1934), who rejected classical theories and neoclassical economic development, exposing a state of equilibrium in the economic environment that applies the principle of "circular flow" of money and goods that is constantly repeated. His studies indicate that it is not possible to obtain profits in one state of equilibrium and instead find the only solution in innovation. Recently, innovation has been defined by Rogers (2003) as an "idea, practice, or object that is perceived as new by an individual or other unit of adoption". Several studies have attested to the importance of the diffusion of innovation in various industries and research areas, such as communication, sociology and marketing (Kennedy, 1983; Macdonald, 1992; Wolfe, 1994; Makkonen and Johnston, 2014).

Following another perspective, Selwyn (2003) attested to the importance of the research area of non-adoption of new technology. Indeed, some scholars have explored limits to innovation diffusion from various points of view, such as MacVaugh and Schiavone (2010), who developed an integrative model of factors limiting the adoption of new technological innovations to demonstrate the possible result of interactions among conditions and domains during new product introduction. With regard to the healthcare system, innovations can be related to the product, process or structure (Varkey et al., 2008; Popkova and Sergi, 2020). Product innovation may refer to goods or services; an example could be innovations in clinical procedures. Process innovations may refer to the production process or delivery of the product (e.g. drugs or medical devices) that allows a significant increase in the value delivered to one or more stakeholders. Finally, structural innovations can have impacts inside and outside the company, creating new business models (e.g. telemedicine) in the healthcare context.

Considering the healthcare ecosystem as innovative is essential to understand the importance of knowledge in the innovation-decision process. Swan et al. (2000) affirmed that interactive innovation processes depend on the integration of knowledge across disparate social communities and require the exploration of knowledge. For instance, knowledge sharing has become an important success factor for micro-firms involved in crowd-based contexts (Dezi et al., 2019; Leone and Schiavone, 2019). The large view of innovation diffusion in the management literature has triggered discussions about knowledge tools and strategies. For instance, real-world data constitute the modern data collection system as the research base of the main pharmaceutical companies operating in global contexts. Based on the large selected patient population, these data scientifically indicate all the values that are helpful to different groups of stakeholders (e.g. healthcare organizations and regional decision makers) to have a correct and global evaluation of clinical and economic trends (Adamson et al., 2008). From a managerial point of view, a knowledge-based health innovation can also be related to the use of MA strategies to support the diffusion of innovative drugs or medical devices (Jarosławski and Toumi, 2011; van de Vooren et al., 2015). Therefore, this knowledge sharing approach requires implementation and exploration in growing service industries to understand the business advantages and promote innovation.

\subsection{Developing intellectual capital innovation in healthcare ecosystems}

The healthcare industry is facing the challenge of improving patient care by harnessing new frontiers of innovation that increasingly enhance the knowledge sharing process. Knowledge sharing is facilitated by the development of intellectual capital (Kianto et al., 2017). In our study, we avoid adopting an interpretation of intellectual capital as a corporate strategic asset (Wiig, 1997; Delgado-Verde et al., 2011). We explore the concept of intellectual capital as a factor strictly related to knowledge sharing; in other words, we consider intellectual capital from a dynamic and malleable perspective intertwined with the process of the creation, reconfiguration, transformation or use of resources (Radaelli et al., 2011). By adopting this mindset, this paper explores the role of intellectual capital during the innovation decision process. Therefore, the pivotal factors of intellectual capital may influence the innovation
Intellectual capital in healthcare organizations

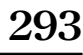


capacity of a healthcare organization. Clarifying the connection between intellectual capital and the knowledge sharing process opens new avenues to shed light on the innovation process. In the healthcare industry, the interconnection is even more consistent because of the complexity and predominance of knowledge-intensive activities from the development of new tools to the delivery of patients. Healthcare organizations function through a wide structured and unstructured sedimentation of formal and informal know-how spread by individuals. This know-how may be observed as files, databases, the adoption of treatment tools and a series of medical practices disseminated throughout healthcare organizations.

To clarify the concept of intellectual capital, we adopt the classical configuration of intellectual capital as the result of three dimensions: human capital, structural capital and relational capital (Nahapiet and Ghoshal, 1998; Subramaniam and Youndt, 2005; Cheng et al., 2010). Human capital is defined as the sum of knowledge, skills and abilities that hinge on individual capabilities; in a nutshell, we can link human capital with education, the entrepreneurial spirit, proactiveness or vocational qualification (McGuirk et al., 2015). Human capital is a crucial element of economic growth theory (Storper and Scott, 2009). It is noted in the literature that there is a positive correlation between firm growth and human capital (Gossling and Rutten, 2007; Santos-Rodrigues et al., 2010). Human capital in healthcare is extremely relevant due to the need for very qualified capabilities in all health activities. Human capital is the embodiment of health knowledge (Storper and Scott, 2009; Santos-Rodrigues et al., 2010). It is also a triggering factor in innovation, and most firm-level innovation cases demonstrate its role in the generation, adoption and diffusion of technical and organizational evolution (Popkova and Sergi, 2020).

Relational capital is described as the knowledge embedded within and used by the interrelation among people in a network (Nahapiet and Ghoshal, 1998). From the perspective of a company, relational capital involves the human resources exploited in determining and managing the relationship of a company towards the external milieu (Martini et al., 2016). It corresponds with all the aspects at the base of a relationship, such as the degree of formality, the propensity to develop new partnerships and the perception of brand image. In a healthcare organization, the role of relationships is even more important than in other organizations because the value chain is formed by many more actors and competences. This fragmentation hinders the development, deployment and diffusion of innovation, which must involve the right combination of actors to achieve successful access for the patient or the end user (Thakur et al., 2012).

According to Aramburu and Saenz (2011), structural capital may be defined as all of the features related to an organization's design, policy configuration, data monitoring procedures and strategy setting. Structural capital in healthcare may be reconfigured by the exploitation of breakthrough technologies; for example, a digital platform may increasingly power a competitive advantage by harnessing the capabilities of boosting interactions and sharing knowledge (Cenamor et al., 2017). Evans et al. (2015) considered the fundamental role of three key factors in connecting intellectual capital and the innovation process in healthcare. They emphasized the importance of 1) creating an efficient knowledge sharing climate in the organization and 2) boosting knowledge sharing activities among healthcare workers and stimulating attitudes towards and intentions to share knowledge.

\subsection{Theoretical speculations}

We aimed to explore the adoption of intellectual capital to promote innovation in healthcare ecosystems. The link between innovation and the implementation of knowledge-based activities is fundamental to the renovation plan for healthcare organizations. Greco and Eisenberg (1993) identified the continuing difficulties in doctors' behavioural changes and health organizations. As affirmed by Evans et al. (2015), doctors are often not direct 
employees of healthcare organizations and may be not interested in contributing to organizational improvements. Patients represent stakeholders who suffer from the continuous discomfort of this system, which is not very flexible and is unprepared for sudden changes in the market (Lowe et al., 2016). The following theoretical speculations can contribute to developing a conceptualization of different features of intellectual capital by emphasizing the role of knowledge sharing as an enabler of innovation (Radaelli et al., 2011; Wang et al., 2014; Leone and Schiavone, 2019).

With regard to human capital for innovation, individual actors must be able to share information to create value among different actors during the innovation process (Rogers, 2003). The crowdfunding phenomenon is an example of how knowledge exchange among creators and backers is fundamental to support the innovation of new products (Zhao et al., 2017; Leone and Schiavone, 2019). The content of information and the mechanisms for its dissemination are often domains of regulated activity in industrial markets (Baldwin and von Hippel, 2010; Kolsarici and Vakratsas, 2010). In these cases, successful diffusion of innovation in the regulated B2B market is likely to occur only if the seller can build and share reliable and compliant information with the other market players through digital platforms (Grewal and Dharwadkar, 2002). This need pushes the innovator in complex systems to implement ad hoc relational marketing strategies aimed at producing and communicating persuasive knowledge that illustrates to buying firms the level of innovation in institutional rules. This need creates essential conditions for the successful diffusion of innovation, such as the opinions of decision makers and the implementation of various initiatives aimed at stimulating communication between buying firms (Woodside and Biemans, 2005).

With regard to relational capital for innovation, a valid suggestion for healthcare organizations could be to participate in the regulatory process. For instance, networkoriented firms can try to develop specific relationships with national institutions and agencies to influence, to some extent, industry regulation and norms (Möller and Halinen, 2017). Another element that industrial firms must carefully assess is how to structure the relationship channels in which innovation spreads (e.g. new drugs or medical devices). Healthcare organizations must consider all the impositions and inducements established by the decision makers at each level (global, national, regional and local). On the other hand, healthcare professionals may establish a direct relationship with patients from a customercentric perspective; indeed, relational capital exerts the strongest and most direct support in fostering innovative practices in public health organizations (Santos-Rodrigues et al., 2010; Martini et al., 2016).

With regard to structural capital for innovation, such elements could both offer opportunities and generate strategic alliances from a market-based and digital perspective. Therefore, it might be useful to introduce a specific figure, such as that of a field intermediary that specializes in the strategic management of technology. This could contribute to increasing the level of involvement in the activities of patients as well as external partners and other stakeholders. Furthermore, healthcare organizations may propose the use of smart IT solutions for healthcare services to guarantee the fluidity of communications from a service-based perspective (Oborn, 2011). The objective is to facilitate patient access to the use of digital service products (e.g. wearable health technologies) and share knowledge among the various actors involved in the service-based system.

\section{Method: a conceptual approach}

Healthcare innovation and the emergence of disruptive care technologies are not topics full of novelty over the last years, indeed, researchers have paid attention on several aspects such as the healthcare innovation network or the care service quality (Dansky and Gamm, 2004; Omachonu and Einspruch, 2010). In this section, we adopted a conceptual approach aimed at 
JIC

22,2

296

reaching overall comprehension of healthcare innovation mechanisms (Doty and Glick, 1994; Jabareen, 2009). We have tracked the pivotal extant studies for catching the roots and dynamics at the base of diffusion of healthcare innovation. We did not adopt a systematic literature methodology, but we scrutinized only the papers that open a discussion about the fundamental linkage between the healthcare innovation and intellectual capital. Therefore, the first step of the research method is finalized to skim healthcare innovation studies.

Our literature review has been modulated by two features: 1) multidisciplinary driven and

2) key concept driven. It means that the paper is oriented to grasp the conceptual aspects, avoiding of being focused on a single specific field of research (i.e. organizational management, innovation management). The initial review of previous studies began with an examination of academic papers that discussed the concept of healthcare innovation dynamics (Lajili, 2015). We aimed to carry out all of key issues and elements argued during the last years. Only in a second step such kind of generality and abstractness allows us to frame the key concepts and categorize them in the intellectual capital perspective (Jaakkola, 2020). The third phase of our conceptual method is the empirical researching of upmost recent healthcare strategy to sustain and promote innovation. In other words, we set a framework that provides sources of evidence about intellectual capital components as drivers for better performing knowledge diffusion and innovation in healthcare industry (Cornelissen, 2017).

\section{A conceptual proposal for managing intellectual capital in healthcare organizations}

The previous section underlined the importance of knowledge sharing in healthcare organizations to promote innovation and examined current studies of intellectual capital in this field of research. Then, we proposed theoretical speculations to theoretically analyse the specific contributions of innovation diffusion studies to the components of intellectual capital (human, structural and relational). In this section, three different knowledge-based activities for healthcare organizations are discussed based on their potential relations to intellectual capital.

These conceptual premises reveal a wide range of meaning for the innovation management literature, in which three perspectives predominate: value co-creation at the human level, MA approach at the relational level and the digital perspective at the structural level (Table 1).

\subsection{Design value co-creation strategy to develop capabilities as human capital}

Human capital is described as the set of knowledge and competencies of an individual actor or the entire organization (Yang and Lin, 2009). Previous studies have attempted to clearly separate individual human capital from collective human capital (Nahapiet and Ghoshal, 1998; Nerdrum and Erikson, 2001). Scholars' adoption of this approach is justified by the objective of investigating the individual perspective of human capital by exclusively examining educational, behavioural, social or relational capabilities as well as the concept of collective human capital, which refers to the exploration of interconnections between individual competencies and organizational capabilities for managing and exploiting resources.

The healthcare process of value creation has been dramatically transformed (Vargo et al., 2008). The process of innovation does not follow the same traditional dynamics as in other industries (Leitner, 2015). The key to access for a full understanding has been completely changed. The innovation process in healthcare hinges on specific knowledge that triggers the development of new products and services. Therefore, the knowledge sharing process has a crucial role in helpfully disseminating the necessary competencies. At this level, it is not 


\begin{tabular}{|c|c|c|c|c|c|c|}
\hline $\begin{array}{l}\text { Types of } \\
\text { intellectual } \\
\text { capital }\end{array}$ & $\begin{array}{l}\text { Research } \\
\text { proposition }\end{array}$ & $\begin{array}{l}\text { Field of } \\
\text { research }\end{array}$ & $\begin{array}{l}\text { Key } \\
\text { assumption }\end{array}$ & References & Research direction & $\begin{array}{l}\text { Intellectual } \\
\text { capital in } \\
\text { healthcare }\end{array}$ \\
\hline \multirow[t]{5}{*}{$\begin{array}{l}\text { HUMAN } \\
\text { CAPITAL }\end{array}$} & \multirow{5}{*}{$\begin{array}{l}\text { Design value } \\
\text { co-creation } \\
\text { strategy to } \\
\text { develop } \\
\text { capabilities } \\
\text { as human } \\
\text { capital }\end{array}$} & $\begin{array}{l}\text { Organizational } \\
\text { study }\end{array}$ & $\begin{array}{l}\text { Human capital } \\
\text { is described as } \\
\text { the set of } \\
\text { knowledge and } \\
\text { competencies }\end{array}$ & $\begin{array}{l}\text { Nahapiet and } \\
\text { Ghoshal (1998) }\end{array}$ & \multirow{5}{*}{$\begin{array}{l}\text { The exploitation of } \\
\text { human capital } \\
\text { provides a valuable } \\
\text { strategy for } \\
\text { managing } \\
\text { knowledge } \\
\text { resources. It plays a } \\
\text { crucial role in } \\
\text { triggering a value } \\
\text { creation process } \\
\text { and boosts } \\
\text { innovation within } \\
\text { healthcare } \\
\text { organizations }\end{array}$} & $\begin{array}{r}\text { organizations } \\
\mathbf{2 9 7}\end{array}$ \\
\hline & & & $\begin{array}{l}\text { referring to an } \\
\text { individual } \\
\text { actor or the } \\
\text { entire } \\
\text { organization }\end{array}$ & & & \\
\hline & & $\begin{array}{l}\text { Product } \\
\text { innovation } \\
\text { management }\end{array}$ & $\begin{array}{l}\text { The role of } \\
\text { intellectual } \\
\text { capital in } \\
\text { enhancing a } \\
\text { firm's ability to } \\
\text { successfully } \\
\text { realize } \\
\text { innovations } \\
\text { and thus } \\
\text { contribute } \\
\text { positively to its } \\
\text { performance }\end{array}$ & Leitner (2015) & & \\
\hline & & $\begin{array}{l}\text { Healthcare } \\
\text { innovation } \\
\text { management }\end{array}$ & $\begin{array}{l}\text { The study } \\
\text { claims that } \\
\text { new } \\
\text { technological } \\
\text { innovations } \\
\text { open the way } \\
\text { toward much } \\
\text { higher } \\
\text { participation } \\
\text { of patients in } \\
\text { diagnosis and } \\
\text { medical } \\
\text { procedures }\end{array}$ & $\begin{array}{l}\text { Piri, and } \\
\text { Asefzadeh } \\
\text { (2006) }\end{array}$ & & \\
\hline & & $\begin{array}{l}\text { Knowledge } \\
\text { management }\end{array}$ & $\begin{array}{l}\text { The studies } \\
\text { disentangle the } \\
\text { mechanisms } \\
\text { linked to the } \\
\text { knowledge } \\
\text { sharing } \\
\text { process in } \\
\text { healthcare } \\
\text { organizations } \\
\text { and their role } \\
\text { in promoting } \\
\text { value co- } \\
\text { creation }\end{array}$ & $\begin{array}{l}\text { Radaelli et al., } \\
\text { (2011) } \\
\text { Radaelli et al., } \\
(2014)\end{array}$ & & $\begin{array}{r}\text { Table 1. } \\
\text { Key works on three } \\
\text { research propositions } \\
\text { about intellectual } \\
\text { capital in healthcare } \\
\text { organizations }\end{array}$ \\
\hline
\end{tabular}


Types of intellectual Research Field of Key capital proposition

research
Organizationa
study

assumption

References

Research direction

RELATIONAL CAPITAL

\section{8}

A market

access approach as relational capital
Relational

capital

involves the

human

resources

exploited in

developing

and managing

the

relationship of

a company

with the

external milieu

Diffusion of

Innovation

Healthcare

innovation

management
The studies

expand on

many aspects

relating to the

adoption of

innovation and

the limits of

conditions and

domains

during new

technology

introduction

The studies

address the

relationships

among

different

health

operators and

the role of

market access

strategies to

promote

healthcare

innovation
Martini et al. Market access

(2016) strategies helps to

exploit relational

capital, providing a

set of elements (e.g.

pricing and

reimbursement

dossier) that

support the adoption of drugs (or medical devices)

at different

geographical levels

Rogers (2003)

Greenlagh

et al. (2008);

MacVaugh

and Schiavone

(2010)

referring to

different groups of

stakeholders (e.g.

international

agencies, regions,

patients)

Table 1. 


\begin{tabular}{|c|c|c|c|c|c|c|}
\hline $\begin{array}{l}\text { Types of } \\
\text { intellectual } \\
\text { capital }\end{array}$ & $\begin{array}{l}\text { Research } \\
\text { proposition }\end{array}$ & $\begin{array}{l}\text { Field of } \\
\text { research }\end{array}$ & $\begin{array}{l}\text { Key } \\
\text { assumption }\end{array}$ & References & Research direction & $\begin{array}{r}\text { capital in } \\
\text { healthcare }\end{array}$ \\
\hline \multirow[t]{5}{*}{$\begin{array}{l}\text { STRUCTURAL } \\
\text { CAPITAL }\end{array}$} & \multirow{5}{*}{$\begin{array}{l}\text { A digital } \\
\text { servitization } \\
\text { strategy for } \\
\text { boosting } \\
\text { structural } \\
\text { capital }\end{array}$} & $\begin{array}{l}\text { Organizational } \\
\text { study }\end{array}$ & $\begin{array}{l}\text { Structural } \\
\text { capital is } \\
\text { defined as all } \\
\text { of the features }\end{array}$ & $\begin{array}{l}\text { Aramburu } \\
\text { and Saenz } \\
(2011)\end{array}$ & \multirow{5}{*}{$\begin{array}{l}\text { The adoption of a } \\
\text { digital service } \\
\text { strategy in } \\
\text { healthcare } \\
\text { organizations } \\
\text { boosts knowledge } \\
\text { sharing and } \\
\text { provides new value } \\
\text { propositions by a } \\
\text { deeper exploitation } \\
\text { of structural capital } \\
\text { The strategy may } \\
\text { (1) reduce the } \\
\text { fragmentation } \\
\text { in knowledge } \\
\text { diffusion } \\
\text { (2) attract new } \\
\text { external actors } \\
\text { (3) activate } \\
\text { "generative" } \\
\text { dynamics }\end{array}$} & $\begin{array}{r}\text { rganizations } \\
299\end{array}$ \\
\hline & & & $\begin{array}{l}\text { related to the } \\
\text { organization } \\
\text { design, policy } \\
\text { configuration, } \\
\text { data } \\
\text { monitoring } \\
\text { procedures } \\
\text { and strategy }\end{array}$ & & & \\
\hline & & $\begin{array}{l}\text { Marketing } \\
\text { strategy }\end{array}$ & $\begin{array}{l}\text { setting } \\
\text { The study } \\
\text { highlights a } \\
\text { strategy of } \\
\text { adding value } \\
\text { to a product by } \\
\text { providing one } \\
\text { or more } \\
\text { coupled } \\
\text { services. }\end{array}$ & $\begin{array}{l}\text { Vandermerwe } \\
\text { and Rada } \\
\text { (1988) }\end{array}$ & & \\
\hline & & $\begin{array}{l}\text { Business model } \\
\text { innovation }\end{array}$ & $\begin{array}{l}\text { The studies } \\
\text { shed light on } \\
\text { the effect of } \\
\text { digitalization } \\
\text { in terms of the } \\
\text { ability to } \\
\text { nimbly attract } \\
\text { more end users } \\
\text { and the } \\
\text { capacity to } \\
\text { speed up } \\
\text { information } \\
\text { flows }\end{array}$ & $\begin{array}{l}\text { Nambisan } \\
\text { et al., (2017) } \\
\text { Danquaha and } \\
\text { Amankwah- } \\
\text { Amoah (2017) } \\
\text { Autio et al., } \\
\text { (2018); Rogers } \\
\text { (2003) }\end{array}$ & & \\
\hline & & $\begin{array}{l}\text { Digital } \\
\text { innovation }\end{array}$ & $\begin{array}{l}\text { "Digital } \\
\text { generativity" } \\
\text { is the capacity } \\
\text { exhibited by } \\
\text { digital } \\
\text { technologies to } \\
\text { produce } \\
\text { unprompted } \\
\text { change by } \\
\text { large, varied, } \\
\text { unrelated, } \\
\text { unaccredited } \\
\text { and } \\
\text { uncoordinated } \\
\text { entities/actors }\end{array}$ & $\begin{array}{l}\text { Nambisan } \\
\text { et al., (2019) }\end{array}$ & & \\
\hline
\end{tabular}


JIC

22,2

\section{0}

trivial to capture where, when and what the capabilities are agglomerating (Radaelli et al., 2014). In the healthcare system, these questions appear even more relevant as the competencies start to go backward from the patient (Peng et al., 2007; Bartel et al., 2011). For instance, the new frontier of telemedicine is supported by much greater participation of patients in diagnosis and medical procedures (Bartel et al., 2014). In this case, to examine the value creation process, we cannot concentrate only on the capabilities of general practitioners or the performance of digital devices; rather, we should extend attention to what is happening to the knowledge sharing process at the level of a patient, who seems to be more integrated in intellectual capital exploitation (Piri and Asefzadeh, 2006; Camelo-Ordaz et al., 2011; Bordoloi et al., 2012). This phenomenon is accentuated when we analyse all smart devices that can monitor specific medical conditions (Schneider et al., 2010). For example, when smart watches are set up to record blood pressure or heart rate, the user (not necessarily a cardiopathic patient) is able to manage some medical competencies that become part of individual human capital; simultaneously, via the Internet, they may become part of collective human capital (Misic and Misic, 2010; Srivastava and Shainesh, 2015).

The backwards reconfiguration follows the human capital flow; for this reason, capturing the dynamics and adopting an efficient strategy to manage knowledge flow is becoming essential to adjust and perform the innovation process (Agarwal et al., 2010, Srivastava and Shainesh, 2015). The dynamics of human capital flow are adopted for better strategic health planning as well. Indeed, the huge amount of patient data in terms of geo-localization, disease or demographic features may be harnessed to identify the factors that discourage people from ceasing medical treatment. This is the case at the University of Florida, where care managers have used data from Google Maps and other free public health data sources to target patients who are not receiving treatment and to reshape communication strategy to extend care service delivery. In this case, human capital plays a role within the value co-creation process to deeply exploit heterogeneous data for strategic planning programmes.

The role of human capital from a collective perspective participates in the evolution of real-time alerting systems. A growing number of hospitals have decided to adopt clinical decision support software that analyses data from patients and improves the responsiveness of the healthcare system in assisting the patient in real time. This system enhances care safety and simultaneously reduces the costs of in-house treatments by enabling the monitoring of patients at home (see Figure 1).

Under these conditions, the healthcare industry should turn to a systemic approach backed by a new perception of collective human capital. This involves taking advantage of each individual competency by facilitating access and exchange. The value arising from the patient or from the data provided by a medical tool should be captured and spread within the innovation process. Such a strategy might provide a more durable competitive advantage by activating unexpressed and peripheral capabilities. This approach resets the centre of human capital generation by conceiving the process as circular rather than linear.

\subsection{A market access approach as relational capital}

The main obstacle for pharmaceutical products is marketing authorization, which may involve many levels, such as price and reimbursement and supply conditions (Toumi, 2017; Koçkaya and Wertheimer, 2018). The exploitation of relational capital is fundamental to achieve trust and the approval of different groups of stakeholders (e.g. international agencies, regions, patients) and to reduce the time to market for a drug or medical device. According to Forcellina and Akannac (2013), MA is "an approach which contains a series of elements such as public and government affairs and advocacy, health economics and outcomes research, pricing and reimbursement strategies and analytics and real-world evidence". Depending on the field of application, MA has multiple meanings; it is a term first proposed by the World Trade Organization (WTO) to consider the condition of the imported goods of a country. 


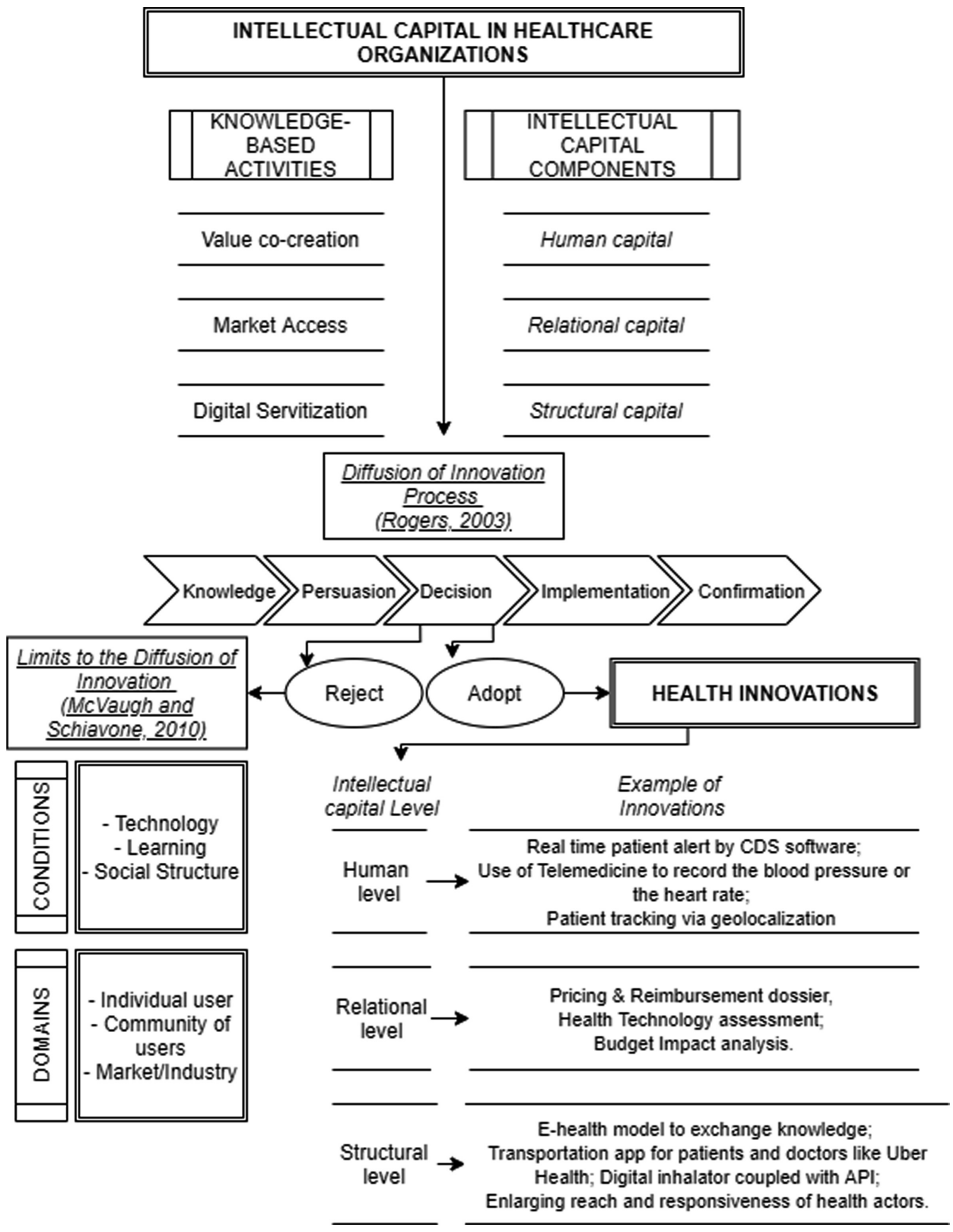

Intellectual capital in healthcare organizations

Source(s): Authors' research

The WTO defined a set of tariff and non-tariff measures to defend home industries using these trade barriers. MA is also a new concept in healthcare and management branches of studies. Several scholars have focused their attention on the real confusion around this new approach, which aims to support the relationships of pharmaceutical companies at different geographical health levels (global, national, regional, local) and to reduce the limits of drug or medical device adoption by patients. 
In the health context, actors are involved in transactions with other stakeholders within an institutional order (international agencies, national agencies, regions and local hospitals). Thus, actors with different decision-making powers (e.g. government agencies) take over specific actions of doctors or the pharmaceutical industry (Smith et al., 2012) by fixing the conditions and domain of adoption (MacVaugh and Schiavone, 2010). Indeed, it is no longer just the physician or the Ministry of Health that can decree access to the market for a given drug or medical device. Regional bodies, health departments and patients themselves are involved in decision making (Koch, 2015).

The role of MA can support communication and drug inclusion at different geographical levels through a deeper exploitation of relational capital with these different groups of stakeholders. For example, one of the main objectives of pharmaceutical companies is to implement a long-term relationship with regional decision makers and to highlight various clinical and economic drug advantages of some health managerial innovations, such as the pricing and reimbursement dossier and health technology assessment (HTA) (see Figure 1). Jommi et al. (2012) noted that MA is mostly associated with public affairs and pricing and reimbursement functions. Thus, the implementation of relational strategies in this renovated and fragmented context has demonstrated a necessary synergy among civil society, research, industry and public and private organizations (Akenroye, 2012). By using the MA approach, healthcare organizations, institutions and pharmaceutical companies can access common information that is able to simultaneously address the interdependent processes of the different innovation adopters.

Finally, the aim of MA can also be related to understanding how organizations co-create value with different stakeholders (e.g. patients, payers) to improve the time to market for innovations in this industry. A MA approach might improve healthcare processes to ensure that all patients obtain and maintain rapid access to drugs or medical devices at the right price (Kumar et al, 2014). For these reasons, MAMs also provide a budget-impact analysis in the relationship with decision makers to show the economic and financial benefits of drug or medical device approval.

\subsection{A digital servitization strategy for boosting structural capital}

Operational practices in the healthcare industry can involve all the treatments, procedures and routines provided to the patient to overcome a psycho-physical problem (Dey et al., 2009). The operations are complex and fragmented; therefore, it may be necessary to research a strategy that potentiates the structure by which knowledge can spread in an increasingly agile and profitable way (Schröter and Lay, 2014). The complexity of health services, which consist of multiple workers, tools, equipment and know-how, leads to a mixture of products and services. For these reasons, adopting a "servitization" perspective seems necessary. "Servitization" is a strategy of adding value to a product by providing one or more coupled services (Vandermerwe and Rada, 1988; Baines et al, 2017). Indeed, some innovative healthcare products may be useless since training for their use is not jointly provided.

The servitization strategy in healthcare is not a new concept (Yip et al., 2015), and digital servitization has been used as a strategy to enable more fluid and efficient dynamics within the healthcare value chain. In other words, Industry 4.0 opens a new avenue for managing structural capital in healthcare. New technologies such as digital platforms are presenting a new way of knowledge sharing by reshaping the role of actors and deeply affecting the structural capital of health organizations (Danquaha and Amankwah-Amoah, 2017). This is due to the characteristics of digitalization, which facilitate a new set of drivers for the greater propagation of data, information and knowledge. Indeed, digital platform deployment may generate disintermediation. This involves narrowing the value chain by shrinking the steps between the upstream and downstream stages. Briefly, digitalization enables direct interactions by harnessing two main points of strength: 1) the ability to attract end users 
in a more agile way and 2) the capacity to breakdown the barriers between goods suppliers and information flows (Nambisan et al., 2017; Autio et al., 2018).

Both of these touchpoints play a crucial role in including the patient and other healthcare actors in the knowledge sharing process by reconfiguring the perimeter of the structure and reshaping the way innovation is generated. This multiplicative resource process has been labelled "digital generativity" by Nambisan et al. (2019). Generativity involves the capacity to exploit unprompted factors by meeting more distant actors. According to Nambisan et al. (2019), generativity hinges on certain features: 1) leverage, which corresponds to the capacity to unleash a deeper and more fruitful exploitation of used inputs; 2) adaptability, which corresponds to agility in modifying certain system features; and 3) ease of mastery and accessibility, which facilitate access to the use of digital service products. These characteristics fit health organizations by enlarging the innovation capacity of the system. An example of health innovation could involve the availability of electronic medical records to collect electronically stored health information in a digital format.

In summary, the adoption of a digital servitization strategy facilitates the exploitation of structural capital (Singh et al., 2011). To grasp the dynamics intertwined with paradigmatic business changes, we provide several examples of digital servitization strategies. Uber entered into a new business segment, the transportation of patients, to meet patients' need to arrive on time to doctor appointments. Therefore, Uber has implemented the Uber Health API as a sort of dashboard that allows healthcare professionals to book a ride for a patient. In this way, the healthcare system enriches the care service, improving the punctuality, accessibility and reach of care services. It is worth highlighting the development of digital inhalators and a combined API. In the battle against chronic respiratory diseases, a classical inhalator is endowed with a digital system that is able to transmit information to the patient's mobile phone. Hence, a traditional medical device such as an inhalator can improve its performance by adding the capacity to record treatment features and collect them on a mobile phone app (Figure 1).

\section{Discussion and implications}

This study attempts to extend the management literature by deepening innovation studies on the use of intellectual capital to promote innovation in service-based organizations. Therefore, this conceptual paper explores the existing intellectual capital literature by considering studies that involve the diffusion of innovations (Rogers, 2003; Greenlagh et al., 2008) and limits to their adoption (MacVaugh and Schiavone, 2010) within the healthcare context. We attempt to generate research propositions to extend previous studies and provide future directions for these research fields. This conceptual paper proposes research implications for the stream of literature on intellectual capital in healthcare organizations (Evans et al., 2015; Pirozzi and Ferulano, 2016; Cavicchi, 2017) to explore three knowledgebased activities (value co-creation, MA and digital servitization) that respond to different intellectual capital levels (human, relational, structural). This approach offers a more solid conceptualization for managing intellectual capital in healthcare organizations than that found in previous studies (Evans et al., 2015; Pirozzi and Ferulano, 2016; Cavicchi, 2017) and creates value in the ecosystem. We provide a conceptual framework for further improvements to this field of research. Thus, the present article offers a theoretical contribution to previous studies of the management of intellectual capital in healthcare organizations that speed up and promote the adoption process in the health context.

The consequence of the restructuring of the health context was the emergence of decentralization and the division of decision-making power. This new ecosystem has therefore increased the complexity from the perspective of the subjects involved and with regard to the operational tools necessary for the marketing authorization of a drug or medical
Intellectual capital in healthcare organizations

303 
JIC

22,2

304

device. An element that must be controlled to promote innovation in healthcare is the structure of the marketing channels in which the innovation spreads (Omachonu and Einspruch, 2010). Managerial implications related to healthcare organizations should also consider all the impositions and inducements established by governments through a MA approach to reduce the time to market for drugs or medical devices. Indeed, managers involved in these practices should use a different set of levers such as managerial, financial, technological or social abilities in order to exchange value and creating long-term relationships with decision makers of a MA process. For these reasons, pharmaceutical companies have to implement ad hoc recruitment plan to have available specific professional figures reducing the time to market for drugs or medical devices.

The prior literature on MA analysed in the previous sections (Smith et al., 2012; Jarosławski and Toumi, 2011; Toumi, 2017) paid great attention to the impact of regulation processes and how MA initiatives can influence, to some extent, the way that decision makers shape and design the processes of knowledge sharing in the context of innovation adoption. On the other hand, such value co-creation elements can both offer opportunities and generate limitations to marketing activities to promote innovation, for instance, with regard to the distribution and pricing policies of the innovation (Grewal and Dharwadkar, 2002).

Therefore, the implementation of value co-creation strategies and linear processes is fundamental to sustain business-to-business relationships in complex contexts such as health services. MA strategies are implemented in this complex context (Jommi et al., 2012; Koch, 2015; Toumi, 2017) as a set of dimensions that promote the diffusion and adoption of the value of a drug or medical device by different subjects, which implies a prior understanding of the institutional context and makes use of various professional actors at different levels. This approach helps to define and frame MA as an innovative strategy by describing the subjects to whom the actions of pharmaceutical companies and professionals in the marketing of the drug are oriented and by defining the background, the value proposition and the levels of activity.

Finally, digital servitization strategies may facilitate the exploitation of structural capital to explore the support of smart IT solutions that provide real-time alerts to healthcare actors (e.g. doctors, nurses) involved in local hospitals or other healthcare organizations (e.g. private clinics, physiotherapy centres). For these reasons, the healthcare industry constitutes a unique range of adjacent business networks in which healthcare actors interact, exchange knowledge and compete in various areas of specialization.

\section{Conclusions}

This study aims to explore the role of intellectual capital in the innovation process. We performed a conceptual study of most updated and innovative knowledge-based activities adopted by healthcare companies to understand whether and how a related approach exists at each level of intellectual capital: human capital, relational capital and structural capital. This paper seeks to develop a conceptual framework to orient researchers and practitioners for a deep comprehension of the healthcare innovation process. This paper can help to more efficiently determine the dynamics and mechanisms based on the innovation process. Human capital may increasingly be a determinant if a healthcare system is ready to adopt a value cocreation approach. In other words, a healthcare company should focus innovation strategy by including more actors who traditionally act as passive users.

The MA strategy is a valuable knowledge asset to penetrate the healthcare market by harnessing all of the features of relational capital, such as the capacity to persuade a commercial partner, the ability to push a product or service or the reliability of medical tools. All of these practices represent a form of relational capital that remains partially unexpressed and may play a key role in the diffusion of knowledge. The emergence of breakthrough technology may reshape the foundations, perimeter and boundaries of healthcare 
organizations. Digital platforms enable the addition of an increasing number of services to the product and vice versa by extending the reach and responsiveness of health ecosystem actors. Structural capital in the era of digitalization has only been partially explored. This paper attempts to shed light on the possible implications of digital servitization on the healthcare innovation process.

This article links two fundamental streams of management studies that respond to innovation diffusion and intellectual capital management. Strategic design and intellectual capital have always followed a common path of evolution. Here, we provide a robust conceptualization of them. While intellectual capital is the concept most frequently investigated, strategic design, as an expression of each level of intellectual capital, remains unexplored. In addition, the literature does not fully examine how strategic design may boost instinctual capital and consequently influence the innovation process.

This paper offers three contributions. First, this study provides insights into the factors that may influence organizations' adoption and management decisions in intellectual capital exploitation. Second, this study expands the generalizability of similar research that has analysed deeply this content without drawing a larger picture that provides an interpretation of the entire healthcare innovation system. Third, this study can support management in clearly understanding the relations among strategies and intellectual capital in generating innovation. However, this study has limitations. This bigger picture is drawn on the basis of intellectual capital configuration. Obviously, intellectual capital is a relevant factor but is not the only factor involved in the process of innovation.

\section{References}

Adamson, D.M., Chang, S. and Hansen, L.G. (2008), Health Research Data for the Real World: The MarketScan Databases, b28, Thompson Healthcare, New York.

Agarwal, R., Gao, G., DesRoches, C. and Jha, A.K. (2010), "Research commentary-the digital transformation of healthcare: current status and the road ahead", Information Systems Research, Vol. 21 No. 4, pp. 796-809.

Akenroye, T.O. (2012), "Factors influencing innovation in healthcare: a conceptual synthesis", The Innovation Journal, Vol. 17 No. 2, p. 1.

Aramburu, N. and Sáenz, J. (2011), "Structural capital, innovation capability, and size effect: an empirical study", Journal of Management and Organization, Vol. 17 No. 3, pp. 307-325.

Autio, E., Nambisan, S., Thomas, L.D. and Wright, M. (2018), "Digital affordances, spatial affordances, and the genesis of entrepreneurial ecosystems", Strategic Entrepreneurship Journal, Vol. 12 No. 1, pp. 72-95.

Baines, T., Bigdeli, A.Z., Bustinza, O.F., Shi, V.G., Baldwin, J. and Ridgway, K. (2017), "Servitization: revisiting the state-of-the-art and research priorities", International Journal of Operations and Production Management, Vol. 37 No. 2, pp. 256-278.

Baldwin, C.Y. and von Hippel, E.A. (2010), Modeling a Paradigm Shift: From Producer Innovation to User and Open Collaborative Innovation, Harvard Business School Finance, Working Paper $\mathrm{N}^{\circ}$ $10-038$.

Bartel, A.P., Phibbs, C.S., Beaulieu, N. and Stone, P. (2011), Human Capital and Organizational Performance: Evidence from the Healthcare Sector (No. W17474), National Bureau of Economic Research, Cambridge, MA.

Bartel, A.P., Beaulieu, N.D., Phibbs, C.S. and Stone, P.W. (2014), "Human capital and productivity in a team environment: evidence from the healthcare sector", American Economic Journal: Applied Economics, Vol. 6 No. 2, pp. 231-59.

Bordoloi, P. and Islam, N. (2012), "Knowledge management practices and healthcare delivery: a contingency framework", Electronic Journal of Knowledge Management, Vol. 10 No. 2, pp. $110-120$.
Intellectual capital in healthcare organizations

305 
JIC

22,2

306

Camelo-Ordaz, C., Garcia-Cruz, J., Sousa-Ginel, E. and Valle-Cabrera, R. (2011), "The influence of human resource management on knowledge sharing and innovation in Spain: the mediating role of affective commitment", International Journal of Human Resource Management, Vol. 22 No. 7, pp. 1442-1463.

Cavicchi, C. (2017), "Healthcare sustainability and the role of intellectual capital", Journal of Intellectual Capital, Vol. 18 No. 3, pp. 544-563.

Cenamor, J., Sjödin, D.R. and Parida, V. (2017), "Adopting a platform approach in servitization: leveraging the value of digitalization”, International Journal of Production Economics, Vol. 192, pp. 54-65.

Cheng, M.Y., Lin, J.Y., Hsiao, T.Y. and Lin, T.W. (2010), "Invested resource, competitive intellectual capital, and corporate performance", Journal of Intellectual Capital, Vol. 11 No. 4, pp. 433-450.

Chou, C.Y., Huang, C.H. and Lin, T.A. (2018), "Organizational intellectual capital and its relation to frontline service employee innovative behavior: consumer value co-creation behavior as a moderator", Service Business, Vol. 12 No. 4, pp. 663-684.

Ciani, O., Armeni, P., Boscolo, P.R., Cavazza, M., Jommi, C. and Tarricone, R. (2016), "De innovatione: the concept of innovation for medical technologies and its implications for healthcare policymaking", Health Policy and Technology, Vol. 5 No. 1, pp. 47-64.

Cornelissen, J. (2017), "Editor's comments: developing propositions, a process model, or a typology? Addressing the challenges of writing theory without a boilerplate", Academy of Management Review, Vol. 42 No. 1, pp. 1-9.

Danquah, M. and Amankwah-Amoah, J. (2017), "Assessing the relationships between human capital, innovation and technology adoption: evidence from sub-Saharan Africa”, Technological Forecasting and Social Change, Vol. 122, pp. 24-33.

Dansky, K.H. and Gamm, L.S. (2004), "Accountability framework for managing stakeholders of health programs", Journal of Health, Organisation and Management, Vol. 18 No. 4, pp. 290-304.

Darroch, J. (2005), "Knowledge management, innovation and firm performance”, Journal of Knowledge Management, Vol. 9 No. 3, pp. 101-115.

Delgado-Verde, M., Martín-de Castro, G. and Navas-López, J.E. (2011), "Organizational knowledge assets and innovation capability: evidence from Spanish manufacturing firms", Journal of Intellectual Capital, Vol. 12 No. 1, pp. 5-19.

Dey, P.K., Hariharan, S. and Ho, W. (2009), "Innovation in healthcare services: a customer-focused approach", International Journal of Innovation and Learning, Vol. 6 No. 4, pp. 387-405.

Dezi, L., Ferraris, A., Papa, A. and Vrontis, D. (2019), "The role of external embeddedness and knowledge management as antecedents of ambidexterity and performances in Italian SMEs", IEEE Transactions on Engineering Management, pp. 1-10.

Doty, D.H. and Glick, W.H. (1994), “Typologies as a unique form of theory building: toward improved understanding and modeling”, Academy of Management Review, Vol. 19 No. 2, pp. 230-251.

Evans, J.M., Brown, A. and Baker, G.R. (2015), "Intellectual capital in the healthcare sector: a systematic review and critique of the literature", BMC Health Services Research, Vol. 15 No. 1, p. 556 .

Ferraris, A., Santoro, G. and Dezi, L. (2017), "How MNC's subsidiaries may improve their innovative performance? The role of external sources and knowledge management capabilities", Journal of Knowledge Management, Vol. 21 No. 3, pp. 540-552.

Forcellina, A. and Akannac, C. (2013), Managing Talent to Meet Pharma's Next Great Challenge: Global Market Access, Egon Zehnder International, Zurich.

Gandal, N., Kende, M. and Rob, R. (2000), "The dynamics of technological adoption in hardware/ software systems: the case of compact disc players", The RAND Journal of Economics, Vol. 31, pp. $43-61$. 
Gössling, T. and Rutten, R. (2007), "Innovation in regions", European Planning Studies, Vol. 15 No. 2, pp. 253-270.

Greco, P.J. and Eisenberg, J.M. (1993), "Changing physicians' practices”, New England Journal of Medicine, Vol. 329 No. 17, pp. 1271-1274.

Greenhalgh, T., Robert, G., Macfarlane, F., Bate, P. and Kyriakidou, O. (2004), "Diffusion of innovations in service organizations: systematic review and recommendations", The Milbank Quarterly, Vol. 82 No. 4, pp. 581-629.

Greenhalgh, T., Robert, G., Bate, P., Macfarlane, F. and Kyriakidou, O. (2008), Diffusion of Innovations in Health Service Organisations: A Systematic Literature Review, Blackwell Publishing, Maiden, Massachusetts.

Grewal, R. and Dharwadkar, R. (2002), "The role of the institutional environment in marketing channels", Journal of Marketing, Vol. 66 No. 3, pp. 82-97.

Jaakkola, E. (2020), "Designing conceptual articles: four approaches", AMS Review, Vol. 10, pp. 1-9.

Jabareen, Y. (2009), "Building a conceptual framework: philosophy, definitions, and procedure", International Journal of Qualitative Methods, Vol. 8 No. 4, pp. 49-62.

Jarosławski, S. and Toumi, M. (2011), "Market access agreements for pharmaceuticals in Europe: diversity of approaches and underlying concepts”, BMC Health Services Research, Vol. 11 No. 1, p. 259.

Jommi, C., Otto, M., Armeni, P. and De Luca, C. (2012), "Market access management by pharmaceutical companies in a complex environment: the Italian case study", Journal of Medical Marketing, Vol. 12 No. 2, pp. 93-103.

Kennedy, A.M. (1983), "The adoption and diffusion of new industrial products: a literature review", European Journal of Marketing, Vol. 17 No. 3, pp. 31-88.

Kianto, A., Hurmelinna-Laukkanen, P. and Ritala, P. (2010), "Intellectual capital in service-and product-oriented companies", Journal of Intellectual Capital, Vol. 11 No. 3, pp. 305-325.

Kianto, A., Sáenz, J. and Aramburu, N. (2017), "Knowledge-based human resource management practices, intellectual capital and innovation”, Journal of Business Research, Vol. 81, pp. 11-20.

Koçkaya, G. and Wertheimer, A. (Eds) (2018), Pharmaceutical Market Access in Developed Markets, SEEd, Torino.

Koch, M.A. (2015), "Pharmaceutical market access: current state of affairs and key challenges-results of the market access launch excellence inventory (MALEI)", Journal of Market Access and Health Policy, Vol. 3 No. 1, 29679.

Kogut, B. and Zander, U. (1992), "Knowledge of the firm, combinative capabilities, and the replication of technology", Organization Science, Vol. 3 No. 3, pp. 383-397.

Kolsarici, C. and Vakratsas, D. (2010), "Category-versus brand-level advertising messages in a highly regulated environment", Journal of Marketing Research, Vol. 47 No. 6, pp. 1078-1089.

Kumar, A., Juluru, K., Thimmaraju, P.K., Reddy, J. and Patil, A. (2014), "Pharmaceutical market access in emerging markets: concepts, components, and future", Journal of market access and health policy, Vol. 2 No. 1, 25302.

Lajili, K. (2015), "Embedding human capital into governance design: a conceptual framework”, Journal of Management and Governance, Vol. 19 No. 4, pp. 741-762.

Leitner, K.H. (2015), "Intellectual capital, innovation, and performance: empirical evidence from SMEs", International Journal of Innovation Management, Vol. 19 No. 05, 1550060.

Leone, D. and Schiavone, F. (2019), "Innovation and knowledge sharing in crowdfunding: how social dynamics affect project success", Technology Analysis and Strategic Management, Vol. 31 No. 7 , pp. 803-816.

Lowe, M.M., Blaser, D.A., Cone, L., Arcona, S., Ko, J., Sasane, R. and Wicks, P. (2016), "Increasing patient involvement in drug development", Value in Health, Vol. 19 No. 6, pp. 869-878.
Intellectual capital in healthcare organizations 
Macdonald, G. (1992), "Health promotion: disciplines and diversity?", Health Promotion: Disciplines and Diversity, Routledge, London, pp. 6-19.

MacVaugh, J. and Schiavone, F. (2010), "Limits to the diffusion of innovation”, European Journal of Innovation Management, Vol. 3 No. 2, pp. 197-221.

Makkonen, H.S. and Johnston, W.J. (2014), "Innovation adoption and diffusion in business-tobusiness marketing", The Journal of Business and Industrial Marketing, Vol. 29 No. 4, pp. 324-331.

Martini, S.B., Corvino, A., Doni, F. and Rigolini, A. (2016), "Relational capital disclosure, corporate reporting and company performance", Journal of Intellectual Capital, Vol. 17 No. 2, pp. 186-217.

McGuirk, H., Lenihan, H. and Hart, M. (2015), "Measuring the impact of innovative human capital on small firms' propensity to innovate”, Research Policy, Vol. 44 No. 4, pp. 965-976.

Misic, J. and Misic, V.B. (2010), "Bridge performance in a multitier wireless network for healthcare monitoring", IEEE wireless communications, Vol. 17 No. 1, pp. 90-95.

Möller, K. and Halinen, A. (2017), "Managing business and innovation networks-from strategic nets to business fields and ecosystems", Industrial Marketing Management, Vol. 67, pp. 5-22.

Mura, M., Lettieri, E., Spiller, N. and Radaelli, G. (2012), "Intellectual capital and innovative work behaviour: opening the black box", International Journal of Engineering Business Management, Vol. 4, Godište 2012, pp. 4-39.

Nahapiet, J. and Ghoshal, S. (1998), "Social capital, intellectual capital, and the organizational advantage", Academy of Management Review, Vol. 23 No. 2, pp. 242-266.

Nambisan, S., Lyytinen, K., Majchrzak, A. and Song, M. (2017), "Digital innovation management: reinventing innovation management research in a digital world”, MIS Quarterly, Vol. 41 No. 1, pp. 223-238.

Nambisan, S., Wright, M. and Feldman, M. (2019), "The digital transformation of innovation and entrepreneurship: progress, challenges and key themes", Research Policy, Vol. 48 No. 8, 103773.

Nerdrum, L. and Erikson, T. (2001), "Intellectual capital: a human capital perspective", Journal of Intellectual Capital, Vol. 2 No. 2, pp. 127-135.

Oborn, E., Barrett, M. and Darzi, A. (2011), "Robots and service innovation in health care", Journal of Health Services Research and Policy, Vol. 16 No. 1, pp. 46-50.

Omachonu, V.K. and Einspruch, N.G. (2010), "Innovation in healthcare delivery systems: a conceptual framework", The Innovation Journal: The Public Sector Innovation Journal, Vol. 15 No. 1, pp. 1-20.

Paoloni, N., Mattei, G., Strologo, A.D. and Celli, M. (2020), "The present and future of intellectual capital in the healthcare sector", Journal of Intellectual Capital, Vol. 21 No. 3, pp. 357-379.

Peng, T.J.A., Pike, S. and Roos, G. (2007), "Intellectual capital and performance indicators: Taiwanese healthcare sector", Journal of Intellectual Capital, Vol. 8 No. 3, pp. 538-556.

Piri, Z. and Asefzadeh, S. (2006), "How Knowledge Management (KM) can be applied to healthcare organizations?”, The Journal of Qazvin University of Medical Sciences, Vol. 10 No. 1, pp. 124-132.

Pirozzi, M.G. and Ferulano, G.P. (2016), "Intellectual capital and performance measurement in healthcare organizations", Journal of Intellectual Capital, Vol. 17 No. 2, pp. 320-350.

Popkova, E.G. and Sergi, B.S. (2020), "Human capital and AI in industry 4.0. Convergence and divergence in social entrepreneurship in Russia", Journal of Intellectual Capital, Vol. 57, pp. 1013-1019.

Radaelli, G., Mura, M., Spiller, N. and Lettieri, E. (2011), "Intellectual capital and knowledge sharing: the mediating role of organisational knowledge-sharing climate", Knowledge Management Research and Practice, Vol. 9 No. 4, pp. 342-352. 
Radaelli, G., Lettieri, E., Mura, M. and Spiller, N. (2014), "Knowledge sharing and innovative work behaviour in healthcare: a micro-level investigation of direct and indirect effects", Creativity and Innovation Management, Vol. 23 No. 4, pp. 400-414.

Robinson, S. (2010), "Market access-the definition depends on the viewpoint", Evidence Matters, Vol. 16, pp. 1-2.

Rogers, E.M. (2003), Diffusion of Innovations, Free Press, New York, p. 551.

Santos-Rodrigues, H., Dorrego, P.F. and Jardon, C.F. (2010), "The influence of human capital on the innovativeness of firms", International Business and Economics Research Journal, Vol. 9 No. 9, pp. 53-63.

Schneider, L., Günther, J. and Brandenburg, B. (2010), "Innovation and skills from a sectoral perspective: a linked employer-employee analysis", Economics of Innovation and New Technology, Vol. 19 No. 2, pp. 185-202.

Schröter, M. and Lay, G. (2014), "Manufacturers of medical technology: servitization in regulated markets", Servitization in Industry, Springer, Cham, pp. 165-176.

Schumpeter, J.A. (1934), The Theory of Economic Development, Harvard University Press Cambridge, Massachusetts.

Selwyn, N. (2003), “Apart from technology: understanding people's non-use of information and communication technologies in everyday life", Technology in Society, Vol. 25 No. 1, pp. 99-116.

Singh, P.V., Tan, Y. and Mookerjee, V. (2011), "Network effects: the influence of structural capital on open source project success", MIS Quarterly, Vol. 35, pp. 813-829.

Smith, B.D. (2012), "Excellence in market access strategy: a research-based definition and diagnostic tool", Journal of Medical Marketing, Vol. 12 No. 4, pp. 259-266.

Srivastava, S.C. and Shainesh, G. (2015), "Bridging the service divide through digitally enabled service innovations: evidence from Indian healthcare service providers”, MIS Quarterly, Vol. 39 No. 1, pp. 245-267.

Storper, M. and Scott, A.J. (2009), "Rethinking human capital, creativity and urban growth", Journal of Economic Geography, Vol. 9 No. 2, pp. 147-167.

Subramaniam, M. and Youndt, M.A. (2005), "The influence of intellectual capital on the types of innovative capabilities", Academy of Management Journal, Vol. 48 No. 3, pp. 450-463.

Swan, J., Newell, S. and Robertson, M. (2000), "Limits of IT-driven knowledge management initiatives for interactive innovation processes: towards a community-based approach", Proceedings of the 33rd Annual Hawaii International Conference on System Sciences, IEEE, p. 11.

Thakur, R., Hsu, S.H. and Fontenot, G. (2012), "Innovation in healthcare: issues and future trends", Journal of Business Research, Vol. 65 No. 4, pp. 562-569.

Toumi, M. (Ed.) (2017), Introduction to Market Access for Pharmaceuticals, CRC Press, Boca Raton.

van de Vooren, K., Curto, A., Freemantle, N. and Garattini, L. (2015), "Market-access agreements for anti-cancer drugs", Journal of the Royal Society of Medicine, Vol. 108 No. 5, pp. 166-170.

Vandermerwe, S. and Rada, J. (1988), "Servitization of business: adding value by adding services", European Management Journal, Vol. 6 No. 4, pp. 314-324.

Vargo, S.L., Maglio, P.P. and Akaka, M.A. (2008), "On value and value co-creation: a service systems and service logic perspective", European Management Journal, Vol. 26 No. 3, pp. 145-152.

Varkey, P., Horne, A. and Bennet, K.E. (2008), "Innovation in health care: a primer", American Journal of Medical Quality, Vol. 23 No. 5, pp. 382-388.

Wang, Z., Wang, N. and Liang, H. (2014), "Knowledge sharing, intellectual capital and firm performance", Management Decision, Vol. 52 No. 2, pp. 230-258.

Wiig, K.M. (1997), "Integrating intellectual capital and knowledge management", Long Range Planning, Vol. 30 No. 3, pp. 399-405.
Intellectual capital in healthcare organizations 
Wolfe, R.A. (1994), "Organizational innovation: review, critique and suggested research directions", Journal of Management Studies, Vol. 31 No. 3, pp. 405-431.

Woodside, A.G., Biemans, W. and Biemans, W.G. (2005), "Modeling innovation, manufacturing, diffusion and adoption/rejection processes", Journal of Business and Industrial Marketing, Vol. 20 No. 7, pp. 380-393.

Yang, C.C. and Lin, C.Y.Y. (2009), "Does intellectual capital mediate the relationship between HRM and organizational performance? Perspective of a healthcare industry in Taiwan", International Journal of Human Resource Management, Vol. 20 No. 9, pp. 1965-1984.

Yip, M.H., Phaal, R. and Probert, D.R. (2015), "Characterising product-service systems in the healthcare industry", Technology in Society, Vol. 43, pp. 129-143.

Zhao, Q., Chen, C.D., Wang, J.L. and Chen, P.C. (2017), "Determinants of backers' funding intention in crowdfunding: social exchange theory and regulatory focus", Telematics and Informatics, Vol. 34 No. 1, pp. 370-384.

\section{About the authors}

Hui Huang is a professor of Chongqing Technology and Business University, received his $\mathrm{PhD}$ from Huazhong University of Science and Technology in 2009. He teaches courses such as advanced financial management, management accounting and asset appraisal and is engaged in researches on financial distress prediction, performance auditing and equity incentive, including the project of implicit compensation of executives in state-owned enterprises from National Social Science Fund and the project of dynamic adjustment of capital structure in listed companies from Ministry of Education. His papers have been published in Corporate Finance Review, China Soft Science and Management Review and his monograph was awarded by Chongqing Social Science in 2018.

Daniele Leone is a Post-doc research fellow at the Department of Management and Quantitative Studies of Parthenope University of Naples, Italy. He received his doctoral degree in management in February 2019 at Federico II University of Naples in Italy. During the past three years he was a Visiting Scholar at the Norwich Business School, University of East Anglia, (UK) and Léonard de Vinci Pôle Universitaire (FR). He is also a member of the editorial board of the International Journal of Globalisation and Small Business. He is guest editor of multiple special issues in journals like Journal of Business and Industrial Marketing and Journal of General Management. His main research areas are innovation management, crowdfunding and healthcare management.

Andrea Caporuscio is a post-doc research fellow at the Department of Management and Quantitative Studies of University of Naples "Parthenope". He has a PhD in International Management focused on the Foreign Direct Investment. He has been Visiting Scholar at the Business Department of Birmingham University. His research interests are related to three mains areas: internationalization, innovation ecosystem and circular economy. He is currently working on a research project on Local Innovation Systems sponsored by the regional Government of Campania. This project is in partnership with the most important Universities of the Region. Andrea Caporuscio is the corresponding author and can be contacted at: andrea.caporusciophd@gmail.com

Sascha Kraus is Full Professor of Entrepreneurship at Durham University Business School. He holds a doctorate in Social and Economic Sciences from Klagenfurt University, Austria, a Ph.D. in Industrial Engineering and Management from Helsinki University of Technology and a Habilitation (Venia Docendi) from LUT University, both in Finland. Before that, he held Full Professor positions at Utrecht University, The Netherlands, the University of Liechtenstein and École Supérieure du Commerce Extérieur, a Grande Ecole in Paris, France.

For instructions on how to order reprints of this article, please visit our website:

www.emeraldgrouppublishing.com/licensing/reprints.htm

Or contact us for further details: permissions@emeraldinsight.com 